\title{
The Impact of Financing on Economic Growth in Saudi Arabia
}

\author{
Mohammed A Al Mahish ${ }^{1,2}$ \\ ${ }^{1}$ Department of Agribusiness and Consumer Science, King Faisal University, Al Ahsa, Saudi Arabia \\ ${ }^{2}$ Department of Agricultural Economics and Rural Sociology, Auburn University, Auburn, Alabama, U.S.A \\ Correspondence: Mohammed Al Mahish, Department of Agribusiness and Consumer Science, King Faisal \\ University, Al Ahsa, Saudi Arabia. E-mail: malmahish@kfu.edu.sa
}

Received: May 5, 2016

Accepted: June 7, 2016

Online Published: July 25, 2016

doi:10.5539/ijef.v8n8p1

URL: http://dx.doi.org/10.5539/ijef.v8n8p1

\begin{abstract}
This paper investigates the impact of the overall financing activities on economic growth in Saudi Arabia. The study developed a financing index that takes into account the overall available credit in Saudi Arabia. The index was shown to be sensitive to economic and political shocks such as the Arab Spring. Using Johnson cointegration approach, the paper found an evidence of long run relationship between real GDP per capita, financing, real interest real, public labor force, and capital. Using a vector error correction model, the paper found a robust estimate that proves the positive impact of financing on economic growth in Saudi Arabia. Furthermore, Granger-Causality Wald test indicates that financing influences economic growth in Saudi Arabia.
\end{abstract}

Keywords: growth, banks, financing, credit, Saudi Arabia

\section{Introduction}

Finance in Saudi Arabia is mainly provided by commercial banks and governmental funds. Commercial banks provide credit to public sector, semi-private sector, and various private sectors such as agriculture, mining, energy, and services sectors. In addition, they provide credit cards and credit facilities to consumers for a variety of purposes such as health care, education, real estate, merchandise, social, and consumption. On the other hand, governmental funds consist of Saudi Agricultural Development Fund, Saudi Credit and Saving Bank, Public Investment Fund, Saudi Industrial Development Fund, and Saudi Real Estate Development Fund. The objective of these governmental funds is to promote economic prosperity and spur economic development. The credit granted by these funds aims at the micro (individual) level to support low income citizens, increase standard of living, and support entrepreneurship. Furthermore, at the macro (sectoral) level it aims at supporting projects that are consistent with the country's development policy and objectives. Figure 1 shows the share of commercial banks credit to total credit. Also, the figure shows the share of governmental funds credit to the total credit in Saudi Arabia from 2010 to 2014. The share of commercial banks credit provided to private sector, semi-private sector, and governmental sector in Saudi Arabia represents over $75 \%$ of the total credit in Saudi Arabia. This is followed by credit provided by commercial banks to consumers, which represents almost $20 \%$ of the total credit. Governmental funds credit ranged from $3 \%$ to $4 \%$. Credit card facilities did not exceed $1 \%$ of the total credit. Thus, it is obvious that credit given to private sector, semi-private sector, and government sector dominate credit market activities in Saudi Arabia. Total commercial bank facilities, combining consumers loans, credit cards, private sector credit, semi-private sector credit, and public sector credit, represent almost $96 \%$ of the total credit market share in Saudi Arabia. 


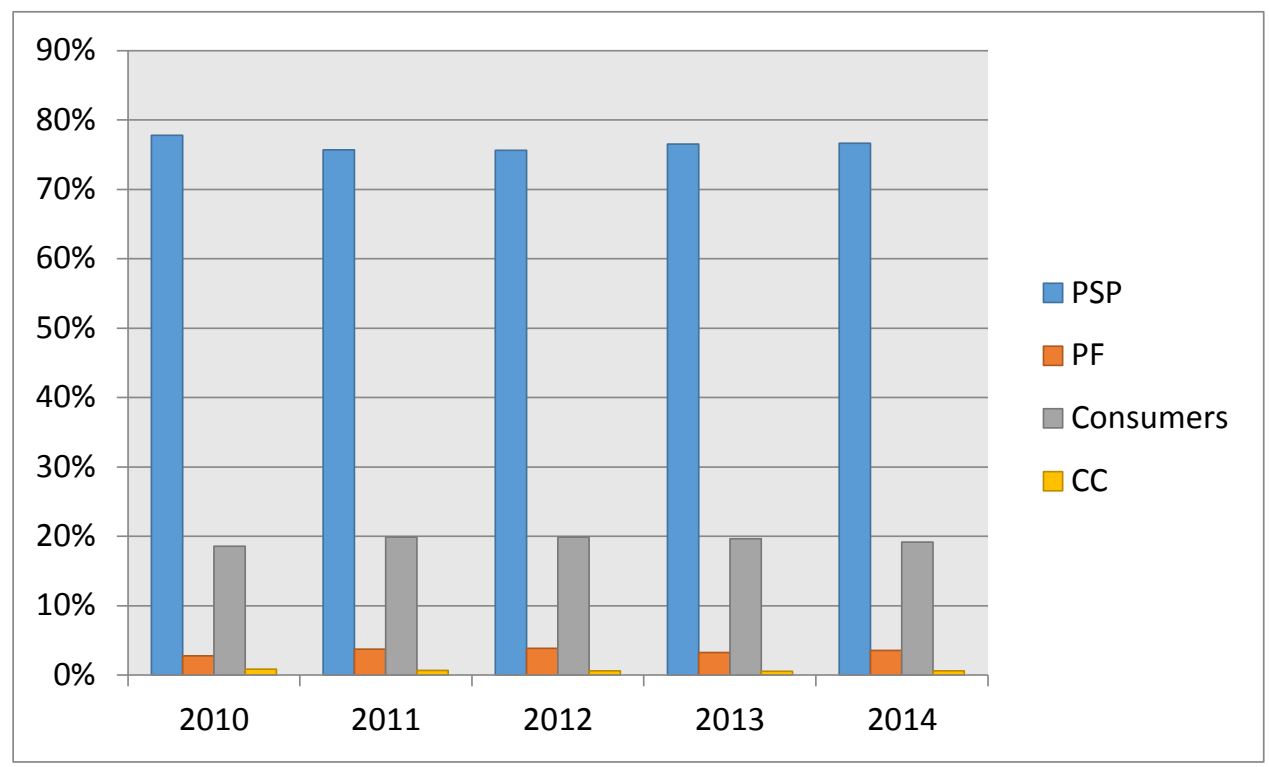

Figure 1. Credit market share in Saudi Arabia

Note. $\mathrm{PSP}=$ credit given by commercial banks to private sector, semi-private sector, and public sector, $\mathrm{PF}=$ credit given by governmental funds, Consumers= loans provided by commercial banks to consumers, $\mathrm{CC}=$ credit card facilities.

The purpose of this paper is to investigate the impact of overall financing, combining sectoral and individual credit, on economic growth in Saudi Arabia. To my knowledge, this is the first study that evaluates the impact of the overall financing facilities on economic growth in Saudi Arabia. Also, the paper aims to examine the causality between financing and economic growth in Saudi Arabia.

\section{Literature Review}

There are many studies that investigated the relationship between financial development and economic growth. These studies included finance in their analysis as a proxy of financial development. However, studies that investigated the impact of credit on economic growth are few in the literature.

Choong (2012) found that credit has a positive and significant effect on per capita GDP growth rate in a panel of 95 developed and developing countries. Önder and Özyıldırım (2013) found that the per capita provincial credit provided by commercial banks in Turkey has a positive and significant effect on local economic growth. Also, they indicated that the state owned banks played a positive role in promoting economic growth. Gozgor and Gozgor (2013) examined the relationship between domestic credit and economic growth as proxied by per capita GDP in twenty Latin American countries. The panel cointegration test showed that there is a long run relationship between domestic credit and per capita GDP in Latin American countries. Also, the direction of causality is from domestic credit to GDP per capita. Uddin, Sjo, and Shahbaz (2013) evaluated the relationship between financial development and economic growth in Kenya using a time series data from 1971 to 2011. The author used domestic credit provided by banking sector as a percent of GDP, domestic credit to private sector as a percent of GDP, and the ratio of money plus quasi money (M2) to money (M1) as proxies for financial development. These variables were then used to construct financial development index using principle component analysis. The authors used Cobb-Douglas production function to estimate the relationship between the log of real GDP per capita as the dependent variable and the logs of financial development, real interest rate, labor force, and capital as the independent variables. The authors estimated their model using error correction model (ECM). In the long run, the authors indicated that a one percent increase in financial development increases economic growth by 0.039 percent. Ben, Boujelbène, and Helali (2014) studied the impact of financial development on economic growth. They used three indicators of financial development: domestic credit, value traded ratio, and issuing banks securities on the financial markets. All these three indicators were divided by GDP. The authors estimated their model using Autoregressive Distributed Lag model (ADRL). Their results showed that private credit has a positive and significant effect on economic growth in the long run. Their results suggest that a one percent increase in credit increases real GDP per capita by 3.36 percent. Also, they found a bidirectional relationship between GDP per capita and private credit. Thus, they concluded that economic growth and financial development can complement each other. Thus, the supply-leading and the demand-following 
hypothesis are supported between economic growth and credit in Tunisia. Anyanwu (2014) found an insignificant negative effect of private sector credit on economic growth in a sample of north and sub-Saharan African countries. Yakubu and Affoi (2014) using a simple OLS regression showed that commercial banks credit in Nigeria has a positive effect on GDP. Nwakanma, Nnamdi, and Omojefe (2014) found a long run relationship between microfinance credit program and economic growth in Nigeria. Also, the causality runs from economic growth to microfinance credit program. Hartarska, Nadolnyak, and Shen (2015) obtained a positive relationship between agricultural credit and GDP growth per rural residents. Pistoresi and Venturelli (2015) indicated that total credit and commercial banks credit, both as a ratio of GDP, positively and significantly affected per capita GDP growth rate in a panel of 53 regions belonging to Germany, Italy, and Spain. Korkmaz (2015) concluded that banking sector credit affected economic growth in a sample of ten European countries. Kandil, Shahbaz, and Nasreen (2015) examine the impact of globalization on financial development on a sample of 32 developed and developing countries, including Saudi Arabia. The authors concluded that financial development has positive impact on economic growth and economic growth spurs financial development. Thus, financial development and economic growth have complementary relationship. Ananzeh (2016) examined the relationship between bank credit and economic growth in Jordan. The author used real GDP as the dependent variable. Total bank credit to all sectors, bank credit to agricultural sector, bank credit to industrial sector, bank credit to construction sector, and bank credit to tourism sector were used as the independent variables. The author found an evidence of long run relationship between the dependent variable and the independent variables. Also, the causality runs from economic growth to credit provided to agricultural sector. Moreover, the study showed a bidirectional causality between economic growth and credit given to construction sector.

Al-Zubi, Al-Rjoub, and Abu-Mhareb (2006) examined the relationship between financial development and economic growth in a panel of eleven Arab countries. The sample consists of Algeria, Bahrain, Egypt, Jordan, Kuwait, Morocco, Oman, Saudi Arabia, Sudan, Syria, and Tunisia. The authors found that the ratio of private credit to total domestic credit is insignificant with respect to per capita GDP using pooled OLS model, random effect model, and fixed effect model. The ratio of private credit to GDP is found to be negative and significant at the one percent level using pooled OLS and negatively significant at the ten percent level using random effect model. The author showed that credit given to public sector as a share of domestic credit is positive and significant at the five percent level with respect to the growth rate of per capita GDP using pooled OLS and fixed effect model. The authors attributed these results to the provision of credit to the public sector and the dominance of public sector on economic activities in the selected Arab countries. Mahran (2012) used the ARDL model to examine the relationship between financial development and real GDP in Saudi Arabia. However, the author found a negative and significant effect of private credit on real GDP. This negative and significant result was present both in the short run and in the long run. The author attributed this result to the high dependence of the Saudi economy on the oil sector as well as to the dominant role played by the government in promoting economic growth. According to the author, this did not give the opportunity to the private sector to play an effective role in promoting economic growth. Ageli and Zaidan (2013) found that credit provided by government specialized bank and commercial banks to private sector has a positive effect on GDP using vector error correction model (VECM). Grassa and Gazdar (2014) examined the impact of total finance, conventional finance, and Islamic finance on economic growth as proxied by the growth rate of real per capita GDP in Gulf Cooperation Council (GCC) countries, excluding Oman. The author found that total domestic credit to private sector as a percentage of GDP is not significant using OLS, Panel estimators (fixed effect and random effect), and GLS. Based on this result, the authors stated that the overall financial system is unimportant to economic growth in the GCC countries. Also, the authors found that conventional finance is insignificant using OLS. However, conventional finance is found to be negatively significant using panel estimator and GLS. Thus, the authors concluded that conventional finance has harmful effect on economic growth in the GCC countries. Moreover, Islamic finance is found to have a positive effect on economic growth in the GCC region using OLS, panel estimator, and GLS. In fact, the author found that a one point increase in Islamic finance increases economic growth by 0.05 percentage points. Al-Malki and Al-Assaf (2014) estimated the impact of financial development, which includes credit provided by banking sector to private sector as a percentage of GDP, on the real per capital GDP using the ARDL model. They found that private credit has a positive and significant impact on economic growth at the five percent level. A one percent increase in private credit is associated with a 0.44 percent increase in real GDP per capita. Samargandi, Fidrmuc, and Ghosh (2014) examined the impact of financial development on real GDP per capita of non-oil sector, GDP per capita of oil sector, and total GDP per capita in Saudi Arabia using the ARDL approach. The authors found that financial development has a positive and significant effect on the non-oil sector. However, financial development is found either insignificant or negatively significant with respect to oil and the overall GDP. 
This paper aims to fill the gap in the literature by analyzing the impact of the overall financing activities on economic growth in Saudi Arabia. To my knowledge, there is no study that evaluates the overall effect of credit on economic growth in Saudi Arabia, combining both credit provided at the consumers level and credit provided at the sectoral level.

\section{Model}

In this paper, I will follow Uddin et al. (2013) approach by using a Cobb-Douglas production function and assuming real interest rate and financing activities as determinants of total factor productivity as below:

$$
y_{t}=\Omega l_{t}^{\beta} k_{t}^{\phi}
$$

Where $\Omega$ is a residual withholding the impact of real interest rate and finance. $y_{t}, l_{t}$, and $k_{t}$ denote real GDP per capita, labor force, and capital, respectively. $\beta$ and $\phi$ denote the variables' partial elasticities.

We can setup the above equation in an estimable form by utilizing the logarithm as below:

$$
l y_{t}=a_{0}+\beta_{1} l f_{t}+\beta_{2} l r_{t}+\beta_{3} l l_{t}+\beta_{4} l k_{t}+u_{t}
$$

Where $f_{t}$ and $r_{t}$ stand for finance and real interest rate, respectively.

\section{Data}

The data for this paper comes mainly from the Saudi Arabian Monetary Agency (SAMA). The real per capita GDP comes from the World Bank, world development indicator. Table 1 shows descriptive statistics of the key variables.

Table 1. Descriptive statistics of the key variables

\begin{tabular}{cccccc}
\hline Variable & $\mathrm{N}$ & Mean & Standard Deviation & Minimum & Maximum \\
\hline GDP per capita & 45 & 90705.37 & 54680.10 & 54916.68 & 241375.96 \\
Real interest rate & 45 & 9.025 & 6.853 & 0.916 & 29.76 \\
Public labor force & 45 & 560696.82 & 301736.25 & 117278.00 & 1240748.00 \\
Capital & 45 & 0.204 & 0.043 & 0.088 & 0.300 \\
\hline
\end{tabular}

The total number of observations used in this study are 45 observations from 1970 to 2014. The variables listed in table 1 are real GDP per capita in Saudi Riyal, real interest rate, public labor force, and capital. Public labor force has been used instead of total labor force due to the unavailability of adequate statistics for total labor force. Also, due to the unavailability of lending interest rate, I used deposit interest rate. There were some missing observations for the nominal interest rate that were recovered using a linear trend method following (Coelli, Rahman, \& Thirtle, 2003). Capital is the share of gross fixed capital formation to GDP.

\section{Financing Index}

Since there are various sources of finance in Saudi Arabia that differ by the end user. Estimating the impact of those funding sources using equation (2) separately will result in multicollinearity and endogeneity issues. On the other hand, aggregating them in one variable may obscure the true relationship of those sources of funding on economic growth. This is due to the fact that this aggregation overlocks the weight of each funding source on the total aggregated variable. Thus, it is important to derive a comprehensive financing activity index that takes into account commercial banks loans to consumers, private sector, semi-private sector, government sector, and credit cards facilities. Also, the index includes total governmental funds financing. Therefore, the financing index will capture the overall financing activities in Saudi Arabia both at the micro level (individual level) and at the macro level (sectoral level). Consequently, the effect of the overall financing activities in Saudi Arabia on economic growth can be better examined.

I used principle component analysis to construct the financing index following (Uddin et al., 2013), (Samargandi et al., 2014), and (Samargandi, Fidrmuc, \& Ghosh, 2015). The variables I used in constructing the financing index are the overall credit provided by commercial banks to public sector, private sector, and semi-private sector as a percentage of GDP. Total credit provided by governmental funds as a percentage of GDP, the share of total consumer loans provided by commercial banks to GDP, and the share of credit cards facilities to GDP. The results of the principle component analysis is shown in Table 2. I selected the first principle component for the construction of the financing index since it has the largest eigenvalue and it accounts for $81.3 \%$ of the standardized variance. Additionally, the first component is a liner combination of the mentioned financing activities with weight given by the eigenvectors. 
Table 2. Principle component analysis

\begin{tabular}{lllllll}
\hline Component & Eigenvalue & Difference & Proportion & Cumulative & Eigenvectors & PC 1 \\
\hline PC 1 & 3.256 & 2.621 & 0.813 & 0.813 & CBC & 0.535 \\
PC 2 & 0.631 & 0.557 & 0.158 & 0.971 & GFC & 0.427 \\
PC 3 & 0.075 & 0.034 & 0.019 & 0.990 & ConC & 0.516 \\
PC 4 & 0.041 & 0.010 & 1.0000 & CC & 0.516 \\
\hline Note CBC=commercial bank credit, GFC= governmental funds credit, ConC= consumer loans, CC = credit cards.
\end{tabular}

Note $\mathrm{CBC}=$ commercial bank credit, $\mathrm{GFC}=$ governmental funds credit, $\mathrm{ConC}=$ consumer loans, $\mathrm{CC}=$ credit cards.

Figure 2 plots the derived financing index. As shown in the figure that the index ranged in value from 0.015 to 0.311 with a tendency to increase over time. A quick lock at the graph shows that the financing index is sensitive to global and local political and economic events. In 1990, the index dropped from 0.12 to 0.08 in response to the Gulf War. The index decreased in 1999 and 2000 in response to the decline in oil prices. The index seems to be slightly affected by the 2006 stock market crash. Also, the index plunged in 2011 due to the Arab spring.

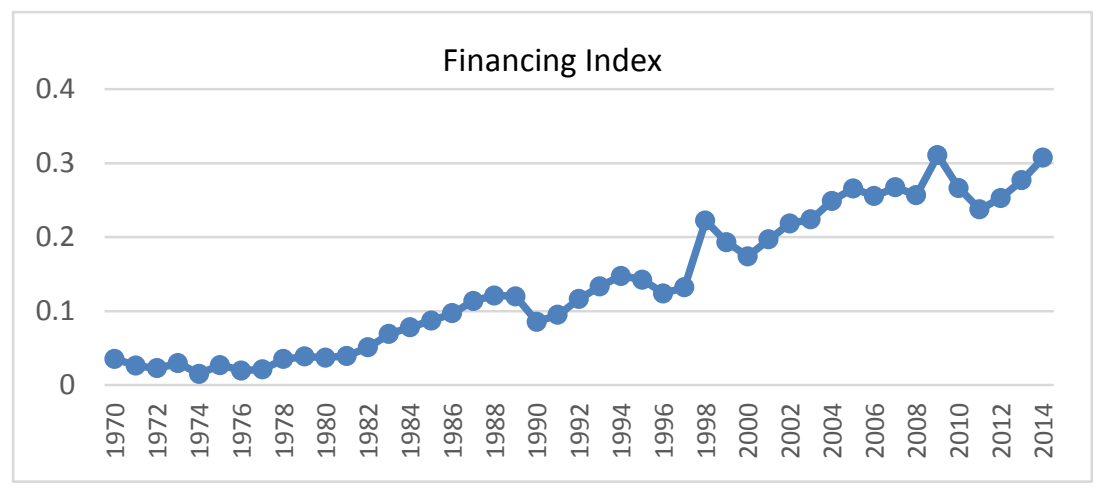

Figure 2. Financing index in Saudi Arabia

\section{Estimation Procedures and Results}

It is well knowen in time series litrature that running regression on a nonstationary data results in spurios regression (Brooks, 2014).Thus, the first step in the analysis is to conduct a unit root test. The results of the augmented Dickey Filler test as reported in table A1 show that all the variables are stationery at the first difference. Since all the variables are integrated of order 1, the long run relationship of the series can be examined using Johnson cointegration techniques. As indicated by (Gökçe \& Çankal, 2013) that the first step of the Johnson cointegratin is the determination of the optimal lag length. The optimal lag length as indicated by Akaike Information Criterion (AIC) is 3. The results of Johnson cointegration test, using both the trace statistcs and the maximum eigenvalue test in table A2 and A3, rejected the null hypothesis of no cointegration at the five percent significance level. This confirms the exsistance of long run relationship among the variables of interest in this paper. If the results of the trace and maximum eigenvalue test differ, it is recommended to rely on maximum eigenvalue test in case of a small sample (Mukhtar \& Rasheed, 2010). In this paper, I relied on the maximim eigenvalue test, which indicates one cointigrating vector. The final step is to estimate the vector error correction model (VECM).The VECM can be expressed as:

$$
\begin{gathered}
\Delta l y_{t}=\beta_{0}+\varphi_{1} \Delta l y_{t-1}+\varphi_{2} \Delta l f_{t-1}+\varphi_{3} \Delta l r_{t-1}+\varphi_{4} \Delta l l_{t-1}+\varphi_{5} \Delta l k_{t-1}+\delta_{1} l y_{t-1}+\delta_{2} l f_{t-1}+\delta_{3} l r_{t-1}+ \\
\delta_{4} l l_{t-1}+\delta_{5} l k_{t-1}+\varepsilon_{t}
\end{gathered}
$$

The long run elasticities can be calculated as $-\left(\delta_{i} / \delta_{1}\right)$. For example, the financing elasticity with respect to real GDP per capita is calculated as $-\left(\delta_{2} / \delta_{1}\right)$.

Table A4 reports parameter estimate and model diagnosis as well. The results of diagnosis check indicate no evidence of autocorelation and the residuals of the financing index are normaly distrubited. The residuals of the other variables are off normal. However, all the variables are homoscedastic. The estimated cointegration vector, long run parameter $(\beta)$, is:

$$
l y_{t}=13.55+0.30 l f_{t}-0.25 l r_{t}-1.29 l l_{t}-0.10 l k_{t}
$$


To ensure that the estimated cointegration vector (4) is significantly different from zero, I imposed restrictions on the cointegration vector. These restrictions test if the estimated long run elasticities are significantly different from zero. The results of the test as shown in Table 3 confirm that all the estimated long run elasticities are significantly different from zero at the one percent level, except the elasticity of capital. The test indicates that the elasticity of capital is not significantly different form zero.

Table 3. Likelihood ratio test on the long run coefficient $(\beta)$

\begin{tabular}{lcc}
\hline Restrictions & Chi-Square & $\mathrm{p}$ \\
\hline$l f=0$ & 51.54 & $<.0001^{* * * *}$ \\
$l r=0$ & 56.91 & $<.0001^{* * * *}$ \\
$l l=0$ & 49.73 & $<.0001^{* * *}$ \\
$l k=0$ & 1.71 & 0.7883 \\
\hline
\end{tabular}

*** = significant at the one percent level.

The estimated long run elasticity of financing with respect to real GDP per capita is positive. It indicates a one percent increase in credit increases real GDP per capital growth by 0.30 percent. Conversely, interest rate has a negative influence on economic growth in the long run. The negative effect of interest rate on the Saudi Arabia's GDP is consistent with (Algahtani, 2015) findings. Public labor force has the largest negative impact on economic growth. This can be attributed mainly to the low labor productivity in the public sector. In the short run, capital has a positive effect on economic growth and financing has a negative effect on economic growth. The negative effect of financing in the short run indicates that most of the short run loans are used for consumption purposes. Thus, they are not invested in productive projects. Furthermore, public labor force and interest rate do not have an effect on economic growth in the short run.

SAMA reported two statistics for fixed capital formation. The value of capital used in estimating equation (4) is fixed capital formation statistics that does not include changes in inventory. To further investigate the impact of capital on economic growth, I re-estimate the model using the second statistics for fixed capital formation that includes changes in inventory. The estimated long run parameter $(\beta)$ is:

$$
l y_{t}=2.74+0.20 l f_{t}-0.10 l r_{t}-1.08 l l_{t}+0.59 l k_{t}
$$

Furthermore, the results of the likelihood test (available on request) indicates that all elasticities, including capital, are significantly different from zero. Thus, a one percent increase in capital increases economic growth by 0.59 percent.

Lastly, I conduct Granger causality test between finance and economic growth as proxied by real GDP per capita. The null hypothesis of the first Granger-Causality test is that economic growth is influenced by itself, and not by financing. Based on the result of Wald test in table 4, I reject the null hypothesis at the one percent significance level. Thus, economic growth is influenced by financing. Furthermore, the null hypothesis of the second test is that financing is influenced by itself, and not by economic growth. The Granger-Causality Wald test indicates that financing is not influenced by economic growth. Thus, I conclude that supply-leading hypothesis hold for the case of Saudi Arabia. However, the results of the Wald test should be interpreted with caution because it is sensitive to different specifications.

Table 4. Granger-Causality Wald test

\begin{tabular}{ccc}
\hline Test & Chi-Square & $\mathrm{p}$ \\
\hline Economic growth is not influenced by financing & 15.04 & $0.0018^{* * *}$ \\
Financing is not influenced by economic growth & 4.77 & 0.1897 \\
\hline
\end{tabular}

**** significant at the one percent level.

\section{Robustness Check}

The purpose of this section is to test the robustness of the results obtained in the previous section. Particularly, this section aims to test how sensitive is the relationship between financing and real GDP per capita to different specifications. The first robustness check is to keep the same variables, but to use different specifications for the VECM. As shown in table 5 that using different specifications, 1-3, for the VECM model did not affect the 
positive impact of financing on economic growth. In scenario 4, I added oil price to the model as represented by Brent since Saudi Arabia's economy rely on oil revenue. The result of the financing variable is still insensitive to the addition of oil price. Scenario 4 indicates that increases in oil price have a positive impact on economic growth. In scenario 5, I added a dummy variable to control for the effect of different kings who ruled Saudi Arabia. The results showed that changes in kings have contributed positively on real GDP per capita growth. The final specification is to add both oil prices and the king dummy as shown in scenario 6 . The results also confirm the robustness of the earlier findings of this paper that financing has a positive effect on economic growth. Furthermore, I rerun the robustness check, 1-6, by using the value of fixed capital formation that includes changes in inventory. The results I obtained (available on request) confirms the insensitivity of the positive influence of financing on economic growth. Moreover, the results showed that capital has a positive influence on economic growth and the positive effect of oil price on economic growth was sensitive to different specifications.

Table 5. Robustness check of the long run parameter $(\beta)$

\begin{tabular}{ccccccc}
\hline Variable & 1 & 2 & 3 & 4 & 5 & 6 \\
\hline$l f$ & 0.307 & 0.200 & 0.206 & 0.123 & 0.447 & 0.284 \\
$l r$ & -0.256 & -0.193 & -0.200 & -0.215 & -0.250 & -0.128 \\
$l l$ & -1.299 & -1.237 & -1.240 & -1.400 & -1.556 & -1.698 \\
$l k$ & -0.095 & -0.076 & -0.077 & -1.026 & -0.164 & -1.209 \\
Brent & - & - & - & 0.382 & - & 0.414 \\
King & - & - & - & - & 0.067 & 0.172 \\
\hline
\end{tabular}

Note. $1=$ No separate drift, but a constant enters via the error correction term, $2=$ there is a separate drift and a linear trend enters via the error correction term, $3=$ Separate linear trend, $4=$ adding oil price, $5=$ adding president dummy, and $6=$ adding both oil price and president dummy.

\section{Conclusion}

This paper showed that financing activities in Saudi Arabia is dominated by commercial banks. Public funds credit represents a small share of the overall credit market in Saudi Arabia. The paper derived a financing index that was a composite of public funds credit and credit facilities provided by commercial banks. The index was developed using principle component analysis. The derived index reacted to economic and political events such as the Gulf War and the Arab Spring. Johnson cointegration approach confirmed the existence of long run relationship between real GDP per capita, financing, real interest rate, public labor force, and capital. The long run parameter $(\beta)$ estimated using the VECM showed that financing has a positive effect on economic growth. On the other hand, real interest rate and public labor force negatively affected economic growth in the long run. Public labor force had the largest negative influence on economic growth. Conversely, Capital has a positive effect on economic growth in the long run. Moreover, the paper showed that short run loans are directed toward consumption and not invested in productive projects. To confirm the robustness of the results, I conducted a various robustness checks using different specifications for the VECM. Also, I added oil prices and dummy variable representing different kings who ruled Saudi Arabia during the timeframe of this study. The positive influence of financing on economic growth was shown to be robust with respect to different specifications. Furthermore, increases in oil prices and changes in kings had a positive effect on real GDP per capita growth. Moreover, the results of Granger-Causality Wald test showed that economic growth is influenced by financing.

\section{References}

Ageli, M., \& Zaidan, S. (2013). Saudi financial structure and economic growth: A Macroeconometric Approach. International Journal of Economics and Finance, 5(3), 30-35. http://dx.doi.org/10.5539/ijef.v5n3p30

Algahtani, G. J. (2015). Impact of rising interest rate on Saudi economy (Paper NO WP/15/4). SAMA Working Paper. Retrieved from http://www.sama.gov.sa/en-US/EconomicResearch/WorkingPapers/IMPACT\%20OF\%20RISING\%20INTE REST\%20RATE\%20ON\%20SAUDI\%20ECONOMY.pdf

Al-Malki, A., \& Al-Assaf, G. (2014). Investigating the effect of financial development on output growth using the ARDL bounds testing approach. International Journal of Economics and Finance, 6(9), 136-150. http://dx.doi.org/10.5539/ijef.v6n9p136

Al-Zubi, K., Al-Rjoub, S., \& Abu-Mhareb, E. (2006). Financial development and economic growth: A new empirical evidence from the MENA countries, 1989-2001. Applied Econometrics and International 
Development, 6-3, 137-150. Retrieved from http://www.usc.es/economet/journals1/aeid/aeid6311.pdf

Ananzeh, I. E. (2016). Relationship between bank credit and economic growth: Evidence from Jordan. International Journal of Financial Research, 7(2), 53-63. http://dx.doi.org/10.5430/ijfr.v7n2p53

Anyanwu, J. C. (2014). Factors affecting economic growth in Africa: Are there any lessons from China? African Development Review, 26(3), 468-493. http://dx.doi.org/10.1111/1467-8268.12105

Ben Jedidia, K., Boujelbène, T., \& Helali, K. (2014). Financial development and economic growth: New evidence from Tunisia. Journal of Policy Modeling, 36(5), 883-898. http://dx.doi.org/10.1016/j.jpolmod.2014.08.002

Brooks, C. (2014). Introductory econometrics for finance (3rd ed.). Cambridge University Press.

Choong, C. K. (2012). Does domestic financial development enhance the linkages between foreign direct investment and economic growth? Empirical Economics, 42(3), 819-834. http://dx.doi.org/10.1007/s00181-011-0455-2

Coelli, T., Rahman, S., \& Thirtle, C. (2003). A stochastic frontier approach to total factor productivity measurement in Bangladesh crop agriculture. Journal of International Development, 15(3), 321-333. http://dx.doi.org/10.1002/jid.975

Gökçe, A., \& Çankal, E. (2013). Balance-of-payments constrained growth model for the Turkish economy. Economic Modelling, 35, 140-144. http://dx.doi.org/10.1016/j.econmod.2013.06.019

Gozgor, G., \& Gozgor, K. (2013). The Relationship between domestic credit and income: Evidence from Latin America. Applied Econometrics and International Development, 13(1), 89-98.

Grassa, R., \& Gazdar, K. (2014). Financial development and economic growth in GCC countries: A comparative study between Islamic and conventional finance. International Journal of Social Economics, 41(6), 493-514. http://dx.doi.org/10.1108/IJSE-12-2012-0232

Hartarska, V., Nadolnyak, D., \& Shen, X. (2015). Agricultural credit and economic growth in rural areas. Agricultural Finance Review, 75(3), 302-312. http://dx.doi.org/10.1108/AFR-04-2015-0018

Kandil, M., Shahbaz, M., \& Nasreen, S. (2015). The interaction between globalization and financial development: New evidence from panel cointegration and causality analysis. Empirical Economics, 49(4), 1317-1339. http://dx.doi.org/10.1007/s00181-015-0922-2

Korkmaz, S. (2015). Impact of bank credits on economic growth and inflation. Journal of Applied Finance \& Banking, 5(1), 51-63. http://www.scienpress.com/journal_focus.asp?main_id=56\&Sub_id=IV\&Issue=1350

MacKinnon, J., Haug, A., \& Michelis, L. (1999). Numerical distribution functions of likelihood ratio tests for $\begin{array}{lllll}\text { cointegration. Journal of Applied } & \text { Econometrics, } & 14(5), & \text { 563-577. }\end{array}$ http://dx.doi.org/10.1002/(SICI)1099-1255(199909/10)14:5<563::AID-JAE530>3.0.CO;2-R

Mahran, H. A. (2012). Financial intermediation and economic growth in Saudi Arabia: An empirical analysis. Modern Economy, 626-640. http://dx.doi.org/10.4236/me.2012.35082

Mukhtar, T., \& Rasheed, S. (2010). Testing long run relationship between exports and imports: Evidence from Pakistan. Journal of Economic Cooperation and Development, 1(31), 41-58. Retrieved from http://www.sesrtcic.org/jecd/jecd_articles/ART08121502-2.pdf

Nwakanma, P., Nnamdi, I., \& Omojefe, G. (2014). From rural to microfinance banking: Contributions of micro credits to Nigeria's economic growth - An ARDL approach. International Journal of Financial Research, 5(3), 73-85. http://dx.doi.org/10.5430/ijfr.v5n3p73

Önder, Z., \& Özyıldırım, S. (2013). Role of bank credit on local growth: Do politics and crisis matter? Journal of Financial Stability, 9(1), 13-25. http://dx.doi.org/10.1016/j.jfs.2012.12.002

Pistoresi, B., \& Venturelli, V. (2015). Credit, venture capital and regional economic growth. Journal of Economics and Finance, 39(4), 742-761. http://dx.doi.org/10.1007/s12197-013-9277-8

Samargandi, N., Fidrmuc, J., \& Ghosh, S. (2014). Financial development and economic growth in an oil-rich economy: The case of Saudi Arabia. Economic Modelling, 34, 267-278. http://dx.doi.org/10.1016/j.econmod.2014.07.042

Samargandi, N., Fidrmuc, J., \& Ghosh, S. (2015). Is the relationship between financial development and economic growth monotonic? Evidence from a sample of middle-income countries. World Development, 68, 66-81. http://dx.doi.org/10.1016/j.worlddev.2014.11.010 
SAS/ETS(R) $\quad 9.2$ User's Guide. (n. d.). Causality testing. Retrieved from http://support.sas.com/documentation/cdl/en/etsug/60372/HTML/default/viewer.htm\#etsug_varmax_sect00 9.htm

Uddin, G., Sjö, B., \& Shahbaz, M. (2013). The causal nexus between financial development and economic growth in Kenya. Economic Modelling, 35, 701-707. http://dx.doi.org/10.1016/j.econmod.2013.08.031

Yakubu, Z., \& Affoi, A. (2014). An analysis of commercial banks' credit on economic growth in Nigeria. Current Research Journal of Economic Theory, 6(2), 11-15. Retrieved from http://www.maxwellsci.com/jp/abstract.php?jid=CRJET\&no=451\&abs=01

\section{Appendix}

Table A1. Augmented Dickey-Fuller unit root test $(\tau)$

\begin{tabular}{ccccc}
\hline \multirow{2}{*}{ Variables } & \multicolumn{2}{c}{ In level I $(0)$} & \multicolumn{2}{c}{ First Difference I $(1)$} \\
\cline { 2 - 5 } & Intercept & Intercept and trend & Intercept & Intercept and trend \\
\hline ly & -2.26 & -1.02 & $-3.37^{* * *}$ & $-4.14^{* * *}$ \\
lf & -0.74 & -2.88 & $-8.92^{* * *}$ & $-8.83^{* * *}$ \\
lr & -0.19 & -1.30 & $-3.53^{* *}$ & $-3.50^{* *}$ \\
ll & -1.42 & -1.56 & $-4.66^{* * *}$ & $-5.04^{* * *}$ \\
lk & -2.71 & -2.72 & $-7.72^{* * *}$ & $-7.72^{* * * *}$ \\
\hline
\end{tabular}

*** and ** denote significance level at the one and five percent, respectively.

ly, lf, lr, ll, and lk = the logarithm of real GDP per capita, financing, real interest rate, public labor force, and capital.

Table A2. Johnson cointegration test (Trace test results)

\begin{tabular}{|c|c|c|c|}
\hline Number of relations & Eigenvalue & Trace statistics & $\mathrm{p}$ \\
\hline $\mathrm{H}_{0}: \mathrm{r}=0, \mathrm{H}_{1} \mathrm{r}=1$ & 0.7578 & $112.0637 *$ & $<.0001$ \\
\hline $\mathrm{H}_{0}: \mathrm{r} \leq 1, \mathrm{H}_{1} \mathrm{r}=2$ & 0.4309 & $52.5063^{*}$ & 0.0170 \\
\hline $\mathrm{H}_{0}: \mathrm{r} \leq 2, \mathrm{H}_{1} \mathrm{r}=3$ & 0.3332 & 28.8284 & 0.0640 \\
\hline
\end{tabular}

Note. Trace statistics indicates two cointegrating equations at the five percent significance level.

*Denotes the rejection of the null hypothesis at the five percent significance level based on (MacKinnon, Haug, \& Michelis, 1999).

Table A3. Johnson cointegration test (Maximum eigenvalue test results)

\begin{tabular}{cccc}
\hline Number of relations & Eigenvalue & Max eigen statistics & $\mathrm{p}$ \\
\hline $\mathrm{H}_{0}: \mathrm{r}=0, \mathrm{H}_{1} \mathrm{r}=1$ & 0.7578 & $59.5574^{*}$ & $<.0001$ \\
$\mathrm{H}_{0}: \mathrm{r} \leq 1, \mathrm{H}_{1} \mathrm{r}=2$ & 0.4309 & 23.6779 & 0.1447 \\
\hline
\end{tabular}

Note. Max eigenvalue test indicates one cointegrating equation at the five percent significance level.

*Denotes the rejection of the null hypothesis at the five percent significance level based on (MacKinnon, Haug, \& Michelis, 1999).

Table A4. Model parameter estimate and diagnoses

\begin{tabular}{|c|c|c|c|c|c|c|c|c|}
\hline \multirow[t]{2}{*}{ Variable } & \multirow[t]{2}{*}{ Estimate } & \multirow[t]{2}{*}{ Variable } & \multirow[t]{2}{*}{ Estimate } & \multirow[t]{2}{*}{ Variable } & \multicolumn{2}{|c|}{ Normality } & \multicolumn{2}{|c|}{$\mathrm{ARCH}$} \\
\hline & & & & & Chi-Square & $\mathrm{p}$ & F-Value & $\mathrm{p}$ \\
\hline $\mathrm{C}$ & $\begin{array}{l}13.556 \\
(2.248)\end{array}$ & & & ly & 22.02 & $<.0001$ & 0.03 & 0.8727 \\
\hline$l y_{t-1}$ & $\begin{array}{l}-0.466 \\
(0.077)\end{array}$ & $\Delta l y_{t-1}$ & $\begin{array}{c}0.530 \\
(0.131)\end{array}$ & $l f$ & 3.71 & 0.1563 & 0.50 & 0.4849 \\
\hline$l f_{t-1}$ & $\begin{array}{c}0.139 \\
(0.023)\end{array}$ & $\Delta l f_{t-1}$ & $\begin{array}{l}-0.129 \\
(0.051)\end{array}$ & $l r$ & 12.79 & 0.0017 & 0.03 & 0.8666 \\
\hline$l r_{t-1}$ & $\begin{array}{l}-0.118 \\
(0.020)\end{array}$ & $\Delta l r_{t-1}$ & $\begin{array}{c}0.016 \\
(0.033)\end{array}$ & $l l$ & 184.17 & $<.0001$ & 0.03 & 0.8669 \\
\hline$l l_{t-1}$ & $\begin{array}{l}-0.599 \\
(0.099)\end{array}$ & $\Delta l l_{t-1}$ & $\begin{array}{l}-0.051 \\
(0.194)\end{array}$ & $l k$ & 11.52 & 0.0031 & 0.73 & 0.3986 \\
\hline$l k_{t-1}$ & $\begin{array}{l}-0.048 \\
(0.008)\end{array}$ & $\Delta l k_{t-1}$ & $\begin{array}{c}0.260 \\
(0.066)\end{array}$ & & & & & \\
\hline Durbin Watson & 2.01 & $\mathrm{R}$-square & 0.73 & & & & & \\
\hline
\end{tabular}

Note. Standard error in parenthesis. 


\section{Copyrights}

Copyright for this article is retained by the author(s), with first publication rights granted to the journal.

This is an open-access article distributed under the terms and conditions of the Creative Commons Attribution license (http://creativecommons.org/licenses/by/3.0/). 